\title{
STRATEGI BERPIKIR HIPOTETIKAL DEDUKTIF DENGAN PHET SIMULATIONS TERHADAP KETERAMPILAN BERPIKIR KRITIS PADA PEMBELAJARAN FISIKA MATERI USAHA DAN ENERGI KELAS X SMA
}

\author{
Nurmutmainna Ramadoan ${ }^{1}$, Dwi Sulisworo ${ }^{2}$,Ishafit Jauhari $^{3}$ \\ ${ }^{1,2,3}$ Magister Pendidikan Fisika, Universitas Ahmad Dahlan Yogyakarta \\ Jl. Pramuka 42,Umbulharjo, Yogyakarta 55161 \\ Email: nurmutmainna.r@yahoo.com
}

\begin{abstract}
Deductive hypothetical thinking strategy is learning that contains an explanation of the principles of the content of the lesson explained in the form of the application of things that are general in matters that are specific. In deductive hypothetical thinking, students are required to be more critical in accepting and understanding what they have learned and experienced themselves in the 21st century. In the 21st century learning, using PhET simulations learning media to understand physics learning is better and more interesting. This study aims to determine the differences in deductive hypothetical thinking strategies with PhET simulations on critical thinking skills compared to conventional learning in Work and Energy subject. This research method is using quasi-experiment, randomized control group pre-test and post-test that is a researcher who has a randomized design with initial tests before learning and final test after learning. The subjects of this study were 10th grade level of SMAN 1 Soromandi, where the 10th grade level of MIPAI was the experiment group with the number of students as much as 26 and 10th grade level of MIPA2 as the control group with the number of students as much as 23. The results of this study concluded that there were differences between experimental groups and control groups, deductive hypothetical thinking is more effective than conventional learning on business and energy material at SMAN 1 Soromandi.
\end{abstract}

Keywords:Strategy, learning,deductive hypothetical thinking, critical thinking, PhET simulations

\begin{abstract}
Abstrak: Strategi berpikir hipotetikal deduktif adalah suatu pembelajaran yang berisi penjelasan tentang prinsip-prinsip isi pelajaran yang dijelaskan dalam bentuk penerapan hal-hal yang bersifat umum pada hal-hal yang bersifat khusus. Pada berpikir hipotetikal dedukif peserta didik dituntut lebih kritis dalam menerima dan memahami apa yang mereka pelajari dan alami sendiri dalam pembelajaran di abad ke-21 pada kurikulum K13. Dalam pembelajaran abad ke-21 untuk lebih memahami pembelajaran fisika lebih menarik mengunakan media pembelajaran PhET simulations. Penelitian ini bertujuan untuk mengetahui perbedaan strategi berpikir hipotetikal deduktif dengan $\mathrm{PhET}$ Simulations terhadap keterampilan berpikir kritis dibandingkan dengan pembelajaran konvensional pada pembelajaran fisika materi Usaha dan Energi. Metode penelitian ini adalah menggunakan quasi esperiment, randomized control group pre-test dan post-test yaitu suatu penelitian yang memiliki rancangan secara acak dengan tes awal sebelum pembelajaran dan tes akhir sesudah pembelajaran. Subyek penelitian ini adalah kelas X SMAN I Soromandi, dimana kelas $\mathrm{X}_{1}$ Mipa sebagai kelas eksperimen dengan jumlah peserta didik sebanyak 26 dan kelas $\mathrm{X}_{2}$ Mipa sebagai kelas kontrol dengan jumlah peserta didik sebanyak 23 . Hasil penelitian ini menyimpulkan ada perbedaan antara kelompok eksperimen dan kelompok kontrol, dan menggunakan berpikir hipotetikal deduktif lebih efektif dari pada pembelajaran konvensional pada materi usaha dan energi di SMAN I Soromandi.
\end{abstract}

Kata kunci:Strategi, belajar, berpikir hipotetikal deduktif, berpikir kritis, PhET simulations 


\section{PENDAhULUAN}

Dalam menghadapi era globalisasi yang penuh tantangan, pendidikan merupakan aspek yang sangat penting karena dengan pendidikan diharapkan mampu membentuk sumber daya manusia yang terampil, kreatif dan inovatif. Menyadari kompleksitas tantangan di masa depan, komisi bidang pendidikan UNESCO (Commision Education for The "21" Century) merekomendasikan empat pilar pendidikan yang dapat dijadikan sebagai landasan pendidikan meliputi: learning to know, yaitu belajar untuk mengetahui dengan cara menggali pengetahuan dari berbagai informasi; Learning to do, yaitu belajar untuk melakukan suatu tindakan atau mengemukakan ide-ide; Learning to be, yaitu belajar untuk menngenali diri sendiri dan beradaptasi dengan lingkungan; dan Learning to live together, yaitu belajar untuk menjalani kehidupan bersama dan bermasyarakat yang saling bergantung, sehingga mampu bersaing secara sehat dan bekerjasama serta mampu menghargai orang lain. Anderson (dalam Suciati, 2015: 31) menyatakan bahwa tren pembelajaran sains abad 21 idealnya diarahkan pada empat komponen yakni: communication, collaboration, critical thinking dan problem solving, creativity dan innovation. Dalam tatanan pendidikan di Indonesia sendiri pendidik mempunyai masalah yang selalu menjadi perhatian serius oleh para ahli pendidikan. Didalam hasil penelitian setidaknya tiga masalah pendidik yang dihadapi Indonesia, yaitu kualitas guru, kesejahteraan guru, dan politisasi guru. Ketiga masalah pendidik di Indonesia akan sangat berpengaruh pada kinerja dan kualitas ketika mereka harus memasuki era persaingan global dalam pembelajaran abad ke-21 yang menuntut seorang pendidik mempunyai kualitas lebih bukan saja bersaing di dunia pendidikan indonesia tapi pada dunia pendidikan di sesama negara ASEAN bahkan diluar negara ASEAN (Sulisworo dkk, 2017:84-86).

Perhatian utama dari peran pendidikan dalam pembangunan adalah bagaimana pendidikan dapat menciptakan sumber daya manusia yang mampu memecahkan masalah menghambat daya saing. Alternatif pertama untuk meningkatkan daya saing bangsa adalah strategi meningkatkan kualitas pendidikan itu sendiri. Dampak dari kualitas pendidikan adalah daya saing bangsa, pada dunia pendidikan sumber daya manusia yang baik adalah bagaimana perbaikan sistem pendidikan secara keseluruhan. Pendidikan disebutkan sebagai bagian dari 12 pilar daya saing suatu negara terkait dengan pendidikan di era global abad ke-21 (Sulisworo, 2016: 130-134). Pada proses pembelajaran di era global abad ke-21 ini teknologi memiliki peran penting sebagai alat komunikasi pengajaran antara pendidik dan peserta didik. Hal ini dikarenakan interaksi antara pendidik dan peserta didik dan di dalam proses tersebut tujuan pendidikan dapat dicapai.

Umumnya para guru pada kelompok mata pelajaran sains khususnya mata pelajaran fisika mengajarkan kemampuan kepada peserta didik hanya sebatas berpikir pada hal-hal yang terbatas sedangkan kemampuan berpikir yang baik dapat diwujudkan dengan mengetahui seberapa besar pengetahuan yang dicapai serta bagaimana mengontrol aktivitas atau proses berpikir peserta didik (Cavdar dan Does 2014: 3; Anam dan Purwanto, 2015: 286). Sedangkan dalam pembelajaran para guru hanya mengutamakan peserta didik untuk mahir dalam penguasaan materi pada pengetahuan deklaratif (Rochim dkk, 2016: 6). Pada pembelajaran berpikir hipotetikal deduktif dalam pembelajaran fisika SMA/MA terdapat fase-fase pada pelaksanaanya dalam pengajaran pada peserta didik untuk membantu terlaksananya dalam pencapaian pembelajaran diterapkan media yang tepat untuk menumbuhkan kreativitas, pada pembelajaran fisika.Dilapangan peserta didik masih menggagap pelajaran yang tidak menarik dan sulit untuk dipahami. 
Pembelajaran dengan menggunakan bantuan media PhET adalah salah satu media komputasi yang menyediakan animasi-animasi fisika yang dijadikan dalam bentuk blog. Dalam PhET Simulations dapat menampilkan materi yang bersifat abstrak dan dapat dijelaskan dengan mudah dan tepat kepada peserta didik (Ratika dan Budi, 2017: 174175). Pada pembelajaran ini dengan berbantuan media PhET simulations dalam berpikir hipotetikal deduktif juga terhadap keterampilan berpikir kritis dimana ini sangat di perlukan pada dasarnya kemampuan peserta didik dapat diasah dan dieksplorasi sehigga dapat membantu peserta didik dalam meningkatkan pemahaman materi yang dipelajari dengan mengevaluasi secara kritis. Jadi berpikir kritis dalam pendidikan merupakan kompetensi yang akan dicapai serta alat yang diperlukan dalam mengkonstruksi pengetahuan yang terdapat dalam pembelajaran abad ke-21 yang berdampak pada hasil pembelajaran karena menggunakan berpikir tingkat tinggi (Muhammad dan Mulyaningsih, 2014:72).

Mata pelajaran fisika penting untuk diajarkan sebagai mata pelajaran tersendiri dengan pertimbangan bahwa selain memberikan bekal ilmu kepada peserta didik mata pelajaran fisika juga sebagai wahana untuk menumbuhkan kemampuan berpikir yang berguna untuk memecahkan masalah di dalam kehidupan sehari-hari. Dalam upaya peningkatan kualitas belajar maka upaya yang ditempuh adalah melalui proses pembelajaran yang mencakup dalam ranah aspek kognitif, afektif dan psikomotorik yang dapat diukur. Selain itu peningkatan mutu diarahkan pula kepada pendidik yang berperan dalam memfasilitasi perkembangan peserta didik di sekolah berpikir yang ditampilkan dalam berpikir kritis sangat tertib dan sistematis sehingga searah dengan pemikiran berpikir hipotetikal deduktif. Oleh karena itu pada pembelajaran hipotetikal deduktif dengan media PhET Simulations terhadap keterampilan berpikir kritis karna fisika diajarkan dengan sesuatu yang lebih menarik sehingga pengetahuan awal peserta didik terhadap pembelajaran sebelum mempelajari materi karena setiap individu mempunyai pengetahuan awal yang berbedabeda.

Berdasarkan penjelasan tersebut, penelitian ini mengambil judul tentang "Strategi Berpikir Hipotetikal Deduktif dengan Phet Simulations terhadap Keterampilan Berpikir pada Pembelajaran Fisika Materi Usaha dan Energi Kelas X SMA. Dalam penelitian ini terdapat tujuan adalah sebagai berikut: Untuk mengetahui perbedaan pembelajaran fisika dengan Strategi Berpikir Hipotetikal Deduktif dengan Phet Simulations terhadap Keterampilan Berpikir Kritis lebih efektif dibandingkan dengan model pembelajaran Konvensional .

\section{KAJIAN TEORI}

\subsection{Pembelajaran fisika di SMA}

Dalam proses pembelajaran fisika mengidentifikasikan terjadinya kegiatan mengajar yang dilakukan oleh pendidik dan kegiatan belajar yang dilakukan oleh peserta didik. Pembelajaran Sains pada era abad ke-21 ini menggunakan pendekatan saintifik dalam sistem pembelajaran di berbagai negara yang sudah ditetapkan melalui pengaturan oleh pemerintah (Anthony, 2016: 613). Di Indonesia pendekatan saintifik diterapkan dalam kurikulum pembelajaran dan seorang pendidik mempunyai peranan yang strategis untuk mempersiapkan generasi muda yang miliki keberdayaan dan kecerdasaan emosional yang tinggi. Untuk berhasil diabad ke-21,orang yang berpendidikan juga harus memiliki keterampilan yang memungkinkan dia untuk berpikir logis dan memecahkan masalah secara efektif dan mandiri (Charles, 2014:85). Adapun ciri dari pembelajaran era abad ke- 
21 dimana siswa dapat belajar mandiri, kapanpun, dimanapun dan dengan metode maupun media apapun. Tiga konsep pendidikan abad ke-21 adalah 21st Century Skills, scientific approach dan authentic assessment. Selain itu pada pembelajaran abad ke-21 di pengaruhi oleh taksonomi Bloom dimana tujuan dari pendidikan dikembangkan untuk mengklasifikasikan pendidikan itu sendiri (Dwyer dkk, 2014:46). Pada tingkat SMA/MA pada pembelajaran abad ke-21 adalah era globalisasi, era dihasilkan produk teknologi dengan kuantitas yang berlimpah dan kualitas yang semakin canggih terutama dalam dunia pendidikan, Pada pembelajaran fisika dipandang penting untuk diajarkan sebagai mata pelajaran tersendiri dengan beberapa pertimbangan, pertama, selain memberikan bekal ilmu kepada peserta didik, mata pelajaran fisika dimaksudkan sebagai wahana untuk menumbuhkan kemampuan berpikir yang berguna untuk memecahkan masalah didalam kehidupan sehari-hari. Kedua, mata pelajaran fisika perlu diajarkan untuk tujuan yang lebih khusus yaitu membekali peserta didik pengetahuan, pemahaman dan sejumlah kemampuan yang dipersyaratkan untuk memasuki jenjang pendidikan yang lebih tinggi serta mengembangkan ilmu dan teknologi yang sangat diperlukan di dunia pendidikan (Mariam, 2017: 3).

\subsection{Berpikir hipotetikal deduktif}

\subsubsection{Pengertian dan Makna Berpikir}

Oxford Advanced Learner's Dictionary, istilah thinking diartikan," ideas or opinions about something". Pemikiran itu adalah idea atau opini, dengan kata lain, orang yang berpikir adalah orang yang memiliki idea atau opini mengenai sesuatu. Pendidikan merupakan suatu usaha untuk mencari makna atau penyelesaian dari sesuatu lebih dekat dikatakan berpikir. Setiap manusia pada hakikatnya pasti selalu berpikir, namun tingkat keluasan berpikir akan selalu berbeda. Keterampilan berpikir lebih kreatif dan inovatif dalam menghadapi permasalahan dan situasi tidak akan dimiliki tanpa adanya pengetahuan yang luas. Hal ini merupakan salah satu tuntutan terhadap mahasiswa keguruan untuk mampu berpikir lebih kritis.

Makna berpikir, pertama, berpikir adalah 'Stream of consciousness'. Arus kesadaran ini muncul dan hadir setiap hari, mengalir tanpa terkontrol sehingga arus kesadaran tersebut dapat dikategorikan pula sebagai bagian dari proses berpikir. Kedua, berpikir adalah imajinasi atau kesadaran. Pada umumnya imajinasi ini muncul secara tidak langsung atau tidak bersentuhan langsung dengan sesuatu yang sedang dipikirkan. Ketiga, berpikir semakna dengan keyakinan (believing), hal itu bisa tampak dalam ekspresinya. Terakhir, berpikir reflektif adalah rangkaian pemikiran yang dianggap terbaik(Sudarma, 2013: 38).

\subsubsection{Hipotetikal deduktif}

Strategi deduktif suatu konsepatau prinsip didefinisikan dan didiskusikan menggunakan label dan istilah yang sesuai dilanjutkan dengan eksperimen untuk mengemukakan gagasan. Dalam pembelajaran secara Universal Hipotetikal adalah Generalitas yaitu membuat pemikiran ilmiah eksprisit. Generalitas suatu proses penalaran yang terletak pada penarikan kesimpulan (Wiratna, 2014: 12). Sedangkan deduktif merupakan pemberian penjelasan tentang prinsip-prinsip isi pelajaran, kemudian dijelaskan dalam bentuk penerapan atau contoh-contohnya dalam situasi tertentu, dalam penggunaan ini menjelaskan teori kebentuk realitas atau menjelaskan hal-hal yang bersifat umum pada hal- hal yang bersifat khusus. Dalam belajar hipotetikal deduktif peserta didik belajar mulai dengan pernyataan"sebab". 
Selanjutnya peserta didik diminta untuk merumuskan kemungkinan jawaban (hipotesis) atas pernyataan tersebut. Kemudian peserta didik diminta untuk menurunkan konsekwensikonsekwensi logis dari hipotesis dan merencanakan serta melakukan eksperimen (eksplorasi). Analisis hasil eksperimen menyebabkan beberapa hipotesis ditolak sedang yang lainnya diterima (fase pengenalan konsep). Pada akhirnya konsep-konsep yang relevan dan pola-pola penalaran yang terlibat didiskusikan, dan diterapkan pada situasi yang lain dikemudian hari diterapkan pada situasi yang lain (Fadilah dkk, 2015: 52; Ariani dkk, 2011: 20).

\subsection{PhET simulations}

UNESCO memberikan definisi "Virtual laboratory is an electronic workspace for distance collaboration and experimentation in research or other creative activity, to generate and deliver results using distributet information and comunikation technologies". Artinya laboratorium virtual adalah ruang kerja elektronik untuk berkolaborasi dan eksperimentasi dalam penelitian dan kegiatan kreatif lainnya, untuk memberikan hasil melalui dan menggunakan teknologi informasi dan komunikasi (Perkins dkk, 2013:18).

Sama seperti simulasi pada umumnya,Virtual Laboratory dimaksudkan untuk menanamkan konsep di mana proses yang harus dilakukan adalah persiapan (preparation), tampilan virtual lab (performance), dan evaluasi proses eksperimen (evaluation). Sejalan dengan ini bahwa fenomena fisika dan konsep - konsep nya yang terkait dengan simulasi serta terkait dengan aplikasi keseharian peserta didik dapat menambah pengetahuan, peserta didik secara visual dan menstimulus lebih banyak untuk mencapai tingkat penguasaan yang tinggi mengenai konsep ilmu fisika, Simulasi PhET mampu melibatkan peserta didik terhadap eksporasi ilmuwan dan hasil pemahaman peserta didik terhadap materi lebih besar dan mendalam (Hariyanto, 2016: 372)

Simulasi- simulasi dalam PhET tersedia secara gratis dan dapat diunduh di alamat: http://www.phet.colorado.edu.

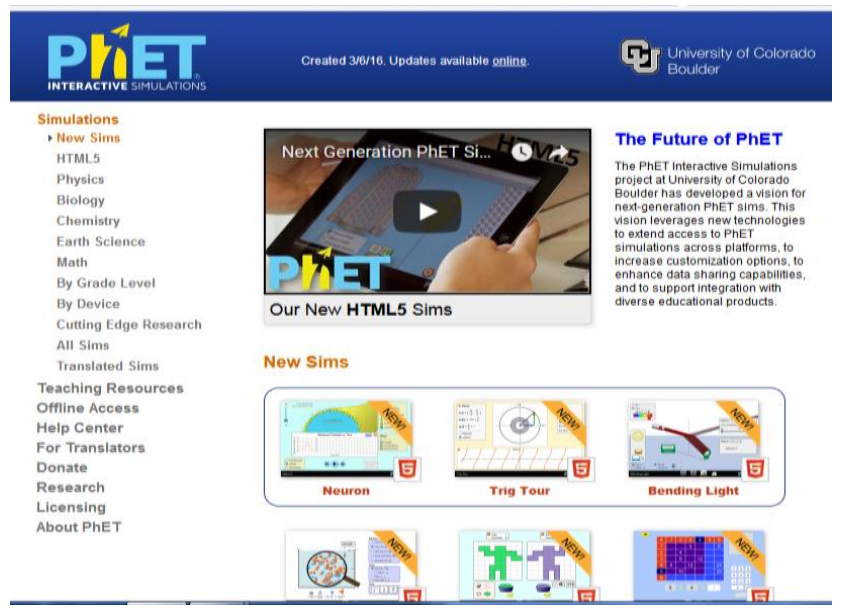

Gambar 1. Tampilan Media PhET Simulation

\subsection{Keterampilan berpikir kritis}

Keterampilan berpikir kritis merupakan bagian dari kemampuan berpikir tingkat tinggi dan keterampilan yang terdapat pada abad 21 bahwa cara terbaik untuk mengatasi keterampilan abad ke 21 adalah untuk menerapkan proses pembelajaran berbasis penemuan yang berfokus 
pada masalah-masalah global yang nyata. Demikian pula fisika perlu di desain untuk mencapai kemampuan berpikir kritis karna dalam proses pembelajaran memandang bahwa fisika adalah ilmu yang berisi fenomena alam diproses dalam penilaian fisik dan empiris yang dikenal sebagai konsep, prinsip, hukum dan prinsip-prinsip yang kemudian digunakan penerapannya dalam teknologi, sehingga fisika bisa dikatakan ada karena proses penemuan. Pada pembelajaran fisika Usaha dan Energi membutuhkan cara berpikir kritis (Jeniffer dkk, 2013: 50; Puspita, 2017:3; Kondakci dan Aydin, 2013: 78).

Dalam Kemampuan berpikir kritis peserta didik sangat perlu dikembangkan demi keberhasilan mereka dalam pendidikan dan dalam kehidupan bermasyarakat, Keterampilan berpikir kritis dapat dikembangkan atau diperkuat melalui proses pembelajaran (Emmanuel dkk, 2017: 20; Ismayanti dan Ishafit, 2017:52). Terdapat hubungan korelasi antara kemampuan berpikir kritis dengan berpikir deduktif dimana kemampuan berpikir kritis merupakan kemampuan berpikir tingkat tinggi yang termaksud dalam kemampuan berpikir deduktif hipotesis yang dapat mempengaruhi hubungan korelasi pada pemahaman peserta didik, ini sesuai dengan indikator berpikir kritis menurut Ennis dimana pada tahap indikator ketiga berpikir kritis peserta didik pada tahap menyimpulkan suatu pembelajaran mendeduksi dan mempertimbangkan hasil deduktif pada fase-fase pembelajaran ini sejalan dengan indikator berpikir kritis yang di kemukakan oleh Ennis (Nevy dkk, 2017: 36). Pembelajaran dengan berpikir hipotetikal deduktif sangat cocok dalam menerapkan keterampilan berpikir kritis karna mereka mengalami sendiri yang mereka pelajari (Fadilla dkk, 2015: 48; Yen dan Halili, 2015: 43).

Berdasarkan uraian diatas dapat disimpulkan bahwa berpikir kritis merupakan proses dimana seseorang memikirkan berbagai hal secara lebih mendalam, berfokus untuk memutuskan apa yang mesti dipercaya atau dilakukan dengan mendefinisikan permasalahan, menilai dan mengolah informasi berhubungan dengan masalah, dan membuat kesimpulan sederhana. Peserta didik yang memiliki keterampilan berpikir kritis akan selalu bertanya pada diri sendiri dalam setiap menghadapi segala persoalan untuk menentukan yang terbaik bagi dirinya (Noviani dkk, 2017 : 148 ; Stobaugh, 2013: 58).

\subsection{Usaha dan energi pada PhET simulasi}

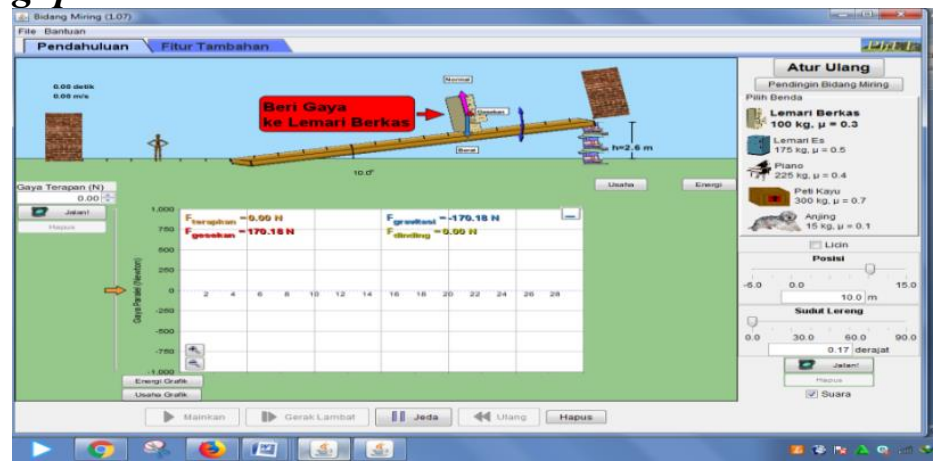

Gambar 2. Bidang miring pada PhET Simulasi

Dalam PhET simulasi terdapat simulasi (virtual lab) yang di dalam nya terdapat salah satu aplikasi pada pembelajaran fisika pada pokok pembahasan usaha dan energi menggunakan aplikasi PhET. Pada materi usaha dan energi simulasi yang dapat digunakan adalah the ramp atau bidang miring. 
Pada simulasi bidang miring peserta didik dapat melakukan percobaan untuk mengetahui usaha, energi, energi potensial, energi kinetik secara mandiri maupun dilakukan secara berkelompok oleh peserta didik.

\section{METODE PENELITIAN}

Penelitian ini dilaksanakan di SMAN 1 Soromandi, dalam penelitian ini ada dua kelas yang digunakan yaitu kelas esperimen (KE) dimana kelas $\mathrm{X}_{1}$ Mipa sebagai kelas esperimen dengan jumlah peserta didik sebanyak 26 dan kelas $\mathrm{X}_{2}$ Mipa sebagai kelas kontrol dengan jumlah peserta didik sebanyak 23. Pada kelas esperimen diterapkan pembelajaran dengan strategi berpikir hipotetikal deduktif sedangkan dikelas kontrol diterapkan pembelajaran konvensional.

Penelitian ini merupakan penelitian esperimen semu (quasi esperimen), model desain penelitian ini adalah randomized control group pre-test dan post-test yaitu suatu peneliti yang memiliki rancangan secara acak dengan tes awal sebelum pembelajaran dan tes akhir sesudah pembelajaran, pada penelitian ini dimana kelas eksperimen diberikan perlakuan dengan pembelajaran strategi berpikir hipotetikal deduktif dengan media PhET Simulasi terhadap keterampilan berpikir kritis pada pembelajaran fisika sementara kelas kontrol tidak, kelas kontrol pengajaran dengan mengikuti cara guru mengajar menggunakan pembelajaran konvensional.

Teknik pengumpulan data dalan penelitian ini, tes berpikir kritis peserta didik dilakukan adalah dengan memberikan pre-test pada kelas eksperimen dan kelas kontrol sebelum treatment dilakukan dan memberikan post-test setelah treatment dilakukan. Post-test dilakukan setelah kelas mendapat pelakuan yang berbeda, sedangkan kelas kontrol Pembelajaran mengunakan model yang diajarkan oleh guru yaitu konvensional. Untuk prettest dan post-test berupa soal yang sama yang diujikan kepada peserta didik untuk mengetahui tingkat keberhasilan dalam pembelajaran.

Instrumen penelitian merupakan perangkat pendukung dalam penelitian, dalam penelitian ini digunakan beberapa jenis instrumen yaitu berupa Rencana pelaksanaan pembelajaran (RPP) RPP digunakan sebagai pedoman pelaksaan pembelajaran agar proses pembelajaran yang telah direncanakan dapat dilaksanakan dengan baik. Rpp yang akan digunakan melalui tahap validasi dari para ahli, Selain itu juga Rpp yang digunakan disesuaikan dengan tahap dalam pelaksanaan strategi berpikir hipotetikal deduktif, Silabus yang digunakan sesuai dengan peraturan yang ditetapkan pemerintah pada kurikulum K13, soal berpikir Kritis, Panduan penggunaan Phet pada pembelajaran dikelas eksperimen maupun kelas kontrol, Soal Pre-test dan Post-test. Soal digunakan dengan taraf Pengetahuan (C1), Pemahaman (C2), Aplikasi (C3) dan Analisa (C4) dalam taksonomi bloom. Pada soal esai sendiri digunakan untuk mengukur keterampilan berpikir kritis peserta didik. Soal esai yang digunakan hanya dengan taraf soal Analisa pada (C4) yaitu soal menganalisis. Soal-soal yang digunakan dalam penelitian harus memiliki kesalihan (validasi) dan keandalan (reablitas) serta uji tingkat kesukaran dan uji daya beda pada soal. Pada teknik analisis data menggunakan uji normalitas dan homogenitas dengan SPSS 16.0.

\section{HASIL DAN PEMBAHASAN}

Berdasarkan analisis dengan menggunakan empat kriteria yaitu validitas, reabilitas, taraf kesukaran dan daya beda soal diperoleh soal yang layak digunakan sebanyak 35 soal dari 40soal yang telah diujikan. Namun hanya 30 soal yang dibutuhkan untuk digunakan dalam pre-test dan post-test. 
Berdasarkan analisis pretest kemampuan kognitif peserta didik, diperoleh hasil ujinormalitas $\mathrm{X}_{\text {hitung }}^{2}<\mathrm{X}_{\text {tabel }}^{2}(\alpha=0,05)$ untuk semua kelas sehingga dapat dikatakan terdistribusi normal dan hasil uji homogenitas diperoleh $\mathrm{X}_{\text {hitung }}^{2}<\mathrm{X}_{\text {tabel }}^{2}(\alpha=0,05)$ sehingga dapat dikatakan populasi adalah homogen.

Setelah itu dilakukan kegiatan proses belajar mengajar sesuai dengan RPP yang telah dibuat. Pembelajaran dilakukan sebanyak 3 kali pertemuan pada tiap kelas dengan alokasi waktu 3 x 45 menit untuk 2JP. Pada penelitian ini menggunakan materi Usaha dan Energi dengan berbantuan PhET Simulations, dalam penelitian peserta didik diajarkan strategi berpikir selama proses pembelajaran ini sesuai yang terkandung dalam Rpp. Pembelajaran strategi yang efektif pada deduktif harus memenuhi tiga kriteria yaitu fase pendahuluan, pengenalan konsep dan aplikasi.

Berdasarkan penelitian yang dilakukan dikelas esperimen diperoleh nilai pretest awal peserta didik sejumlah 70,68 dan dikelas kontrol diperoleh sebesar 51,31. Pada kelas eksperimen tingkat pengetahuan awal peserta didik lebih tinggi dibandingkan dengan terdapat pada kelas kontrol. Pada proses pembelajaran yang ingin dilihat adalah cara berpikir peserta didik selama proses pembelajaran berlangsung. Post test pada pembelajaran dikelas eksperimen diperoleh nilai sebesar 100,00 dan dikelas kontrol sebesar 70,26.

Berpikir kritis diujikan dengan soal dengan taraf kemampuan C4 (analisis) dan berdasarkan analisis diatas dapat diketahui bahwa menerapkan pembelajaran fisika dengan berbantuan media PhET Simulations mampu menumbuhkan kemampuan berpikir peserta didik pada proses pembelajaran dikelas esperimen dan kelas kontrol. Hal tersebut disebabkan karena $\mathrm{PhET}$ sebagai media virtual dapat menjelaskan dan memperlihatkan dan memudahkan pembelajaran materi usaha dan energi pada aplikasi bidang miring.

\section{PENUTUP}

\subsection{Kesimpulan}

Pembelajaran fisika dengan strategi berpikir hipotetikal deduktif di kelas eksperimen lebih baik dibandingkan degan pembelajaran model konvensional dikelas kontrol Sehingga dapat disimpulkan bahwa Strategi Berpikir Hipotetikal Deduktif dengan Phet Simulations terhadap Keterampilan Berpikir pada Pembelajaran Fisika Materi Usaha dan Energi, terbukti dapat menumbuhkan cara berpikir peserta didik dalam proses pembelajaran. Pada pembelajaran dengan strategi berpikir hipotetikal deduktif peserta didik dari awal hingga akhir dituntuk aktif dalam pembelajaran, dan pendidik hanya sebagai fasilitator dalam pembelajaran

\subsection{Saran}

Berdasarkan simpulan dari penelitian yang telah dilakukan, dan agar proses pembelajaran fisika menjadi lebih baik dan lebih efektif hendaknya seorang pendidik lebih bervariasi dalam penggunaan metode belajar dan penting menggunakan media pembelajaran dalam proses belajar mengajar.

\section{DAFTAR PUSTAKA}

Anam dan Purwanto. 2015. Evektivitas Pembelajaran Berbasis Metakognisis Untuk Meningkatkan Kemampuan Berpikir Kritis dan Minat Belajar Fisika Peserta Didik. Prosiding Seminar Nasional Sains dan Pendidikan Sains 5(1), 285-294.

Anthony. 2016. Association of American Law Schools Southwestern Law School. Journal 
of Legal Education 34 (4), 612-618.

Ariani, Hartono dan Hiltrimartin. 2017. Kemampuan Pemecahan Masalah Matematika Siswa pada Pembelajaran Matematika menggunakan Strategi Abduktif - Deduktif di SMA Negeri 1 Indralayu Utara. Jurnal Elemen Pendidikan Matematika 3(1), 16-20.

Arikunto. 2014. Dasar- dasar Evaluasi Pendidikan. Jakarta: Bumi Aksara

Cavdar dan Doe Sue. 2014. Learning through Writing Teaching Critical Thinking Skills in Writing Assignments: Colorado State University.

Charles Kivunja. 2014. Century Skills Change pedagogjes A pedagoqical paradiqm shift from Vygotyskyian social Conctructivim to critical Thinking Problem soving and siemend digital Connectivm.

Dwyer, Hogan and Stewart . 2014. An Integrated Critical Thinking Frame Work For the 21 st Century. Thinking and Creativity12(1), 43-52.

Emmannel, Lily, Esther, Fortress, Ayinuda. 2017. The Role of GSP in Devoloping critical Thinking Skills In Students in Nigerian Universities International. Jurnal of Educational investigation4 (4), 19-31.

Fadilah, Abdul dan Ahmad. 2015. Pengaruh Model Berpikir Siklus Belajar Hipotetikal Pinrang. Jurnal Sains dan pendidikan Fisika 11(1), 49-56. deduktif terhadap Keterampilan berpikir kritis peserta didik kelas XII IPA SMA Negeri 4.

Hariyanto. 2016. Pengaruh Discovery Learning Berbantuan Paket Program Simulasi PhET Terhadap Prestasi Belajar Fisika. Jurnal pendidikan dan kebudayaan 1(3), 365-386.

Ismayati, Q.D dan Ishafit. 2016. Peningkatan kemampuan berpikir kritis dan kreatif Siswa kelas X SMK Ma'arif NU 1 Ajibarang Materi Perubahan Wujud Zat dengan Pengembangan modul pembelajaran Fisika Menggunakan pendekatan Lingkungan. Prosiding SPFA (hlm 51-55). Universitas Ahmad Dahlan.

Jeniffer S. R, Bretel, Dolipas, Brendo, Vildamor. 2013. Higher Order Thinking Skills And Academic Performance In Physics of College Students A Regression Analysis. International Journal Of Innovative Interdisciplinary Research4(1), 48-60.

Kondakci, E.U dan Aydin, Y.C. 2013. Predicting Critical Thinking Skills of University Students Through Metacognitive Self- Regulation Skills and Chemistry SelfEfficacy. Educational Sciences : Theory dan Practice 13(1), 77- 88.

Lawson, A.E. 2014. Allchin's Shoehorn or Why Science Is Hypothetica- deductive.Science and Education 12 (2), 331-337.

Mariam Ar.R. 2017. Inductive - Deductive Approach to improve Mathematical Problem Solving for Juniore High School. Journal of Physic 1(1), 1-6.

Muhammad dan Mulyaningsih . 2014. Penerapan Pembelajaran Fisika Pada materi Cahaya dengan Media PhET Simulations Untuk Meningkatkan Pemahaman Konsep Siswa di SMPN 7 Bojonegoro. Jurnal Inovasi Pendidikan 3 (4), 65-72.

Nevy N. H, Wiyanto dan Achmad. 2017. Analisis Kemampuan berpikir deduksi hipotesis terhadap pemahaman konsep rangkaian resistor pada listrik arus searah. Physics communication 1(1), 35-42. 
Noviani, Hartono dan Rusilowati. 2017. Analisi Pola Pikir Siswa dalam Menyelesaikan Soal sains Ditinjau dari Kemampuan Berpikir Kritis dan kreatif serta Literasi Sains. Journal Of Innovative Science Education 6(2), 148-156.

Perkins, Adams, Dubson, Finkelstein, N. S and Wieman. 2013. PhET Interactive Simulations for Teaching and Learning Physics. The Physics Teacher 44 (8), 18- 22.

Puspita et. 2017. Analysis of Critical Thinking Skillsa on The Topic of Static Fluid. Journal of physics. Conference Series Journal of Physics 1(1), 1-4.

Rantika dan Budi. 2017. Pembelajaran Fisika dengan Model Inkuiri Terbimbing Berbantuan Media PhET Untuk Meningkatkan Keterampilan Berpikir Kritis Siswa pada Materi Fluida. Jurnal Pendidikan Fisika dan Aplikasinya 2(4) 174-175.

Rochim, Sudarisman dan Suparmi. 2014. Pembelajaran Biologi Model Siklus Belajar Hipotetikal Deduktif dengan Media Rill dan Media Virtual ditinjau dari kemampuan Penalaran Analitis dan Gaya Belajar Siswa. Jurnal Pendidikan 1 (2), 6-10.

Stobaugh,R. 2013.AssessingCriticalThinkinginMiddle and High SchoolsMeeting theCommon Core. New York, Taylor and Francis Group.

Suciati Ayu, Putu A, Gan S. 2014. Pengaruh Model Pembelajaran Siklus Belajar Hipotetikal Deduktif dengan Setting 7E Terhadap Hasil Belajar IPA Ditinjau dari Sikap Ilmiah Siswa SMP. e- Journal Program Pascasarjana Universitas Pendidikan Ganesha 4 (2), 8-14.

Sudarma, 2013. Mengembangkan Keterampilan Berpikir Kreatif. Jakarta: Grafindo Persada.

Sulisworo. 2016. The Contribution of the Education System Quality to Improve the Nation's Competitiveness of Indonesia. Journal of education and Learning 10(2). 127- 138.

Sulisworo, Nasir dan Maryani. (2017). Identification of teachers' problems in Indonesia on facing global community. International Journal of research Studies in Education 6(2), 81-90.

Wiratna, Sujarweni. 2014. Metodologi Penelitian. Yogjakarta : Pustaka Barupres.

Yen dan Halili. 2015. Effective Teaching Higher Orde Thinking (HOT) in Education. The Online Journal of Distance Education and E-Learning 3(2), 41-47. 